\title{
Maya Angelou's Growing Up Poor, Black and Female
}

\author{
Dr. Minu Kundi \\ Assistant Professor \\ Department of English \\ SCERT, Solan \\ Solan, Himachal Pradesh, India \\ minks34@gmail.com
}

\begin{abstract}
African American literature is the literature of pain and survival, of triumphs and defeats, of fears and dreams, and of struggle for freedom, equality and identity, produced by the oppressed ones. Black women have used life writing to discover or assert their identity. As they record their experiences they see the critical paths established by the oppressive forces of racism, classicism and sexism. In exploring what it means to be poor, black and female, they present mirror images of 'self' and the 'other' to the world. Within the marginalized blacks in America, women are at triple disadvantage. Being poor, black and female makes them most vulnerable and easy target for the male dominated community. Maya Angelou's life writing I Know Why the Caged Bird Sings (1969) tells the story about a black female's hard life growing up in the American South during the 1930s and 40s. In it Angelou recounts the events of her life in chronological order amidst the racist and sexist American society. She portrays most of her difficult life events from the age of three to sixteen in her life writing showing her hard upbringing, poverty, racism and sexual abuse.
\end{abstract}


Keywords - African American Literature, Life Writing, Oppressed, Identity and Marginalized.

The birth of African American literature is a witness to the irresistible human urge for freedom. It provides fertile ground for the creation of new literature that is produced by the oppressed ones. Generally, Africans were considered an inferior race, incapable of producing literature. The Scottish philosopher David Hume asserts, "I am apt to suspect the negroes, and in general all the other species of men to be naturally inferior to the whites. There never was a civilized nation of any other complexion other than white," ("Go There To Know There: Phillis Wheatley: African American Foremother of Poetry," web. 13 Sept. 2016) yet African Americans produced literature that has both richness and variety. It is the literature of pain and survival, of triumphs and defeats, of fears and dreams, and of struggle for freedom, equality and identity.

"Black women have repeatedly asked themselves: how does a black woman handle the claims of being both a black and a woman? There has been no simple answer because the solution varies with each individual. Some women see themselves as being black first and female second; others reverse that order. Still others see the condition more fluidly and believe that the claims don't conflict. They see black women as people and their race and sex as aspects which contribute to their total being" (Scott PDF). In an attempt to answer this question, black women have used life writing to discover or assert their identity. Writing is an assertion of self as well as an expression of search for dignified ethnic identity.

Life writing "is a form of therapy, self-healing, and emotional release... a source of pleasure, creativity, and self-affirmation... an act of remembering, self-defense, or survival" (Bell-Scott 19-20). In a unique and personal tone, Black women speak emphatically of their concerns and ring out their voices profoundly sharing their experiences that cross class, cultural and geographical boundaries. As they record their experiences they see the critical 
paths established by the oppressive forces of racism, classicism and sexism. The life experiences of these women are running commentaries of their personal journeys from childhood into womanhood. In exploring what it means to be poor, black and female, they present mirror images of 'self' and the 'other' to the world. The presentation of the knowledge of their 'self' to others through life writing is significant because it provides the readers or listeners with personal perceptions that determine their self-identity, which is necessarily reliant on their culture, environment, upbringing, general background and other factors that substantially impact their lives. "Moving from silence into speech is for the oppressed, the colonized, the exploited, and those who stand and struggle side by side a gesture of defiance that heals, that makes new life and new growth possible. It is that act of speech, of 'talking back,' that is no mere gesture of empty words, that is the expression of our movement from object to subject - the liberated voice" (hooks, Talking Back 9).

Within the marginalized blacks in America, women are at triple disadvantage. Gloria Wade-Gayles aptly describes the precarious position of African American women: "American is an oppressive system that divides people into groups on the basis of their race, sex and class, creating a society in which a few have capital and therefore are able to influence the lives of many. There are three major circles of reality in American society, which reflect degrees of power and powerless. There is a large circle in which white people, most of them men, experience influence and power. Far away from it there is a smaller circle, a narrow space in which black people regardless of sex, experience uncertainty, exploitation and powerlessness. Hidden in this second circle is a third, a small, dark enclosure in which black women experience pain, isolation and vulnerability" (3-4). Being poor, black and female makes them most vulnerable and easy target for the male dominated community.

Maya Angelou is one of the most accomplished and powerful voices of African American literature. Her work has a deep feministic strain which strongly connects her with 
the black feminist literary tradition. She is best known for her strong portrayal of African American women. I Know Why the Caged Bird Sings (1969) tells the story about black female's hard life growing up in the American South during the 1930s and 40s - the segregated era characterized by discrimination. The title of the book is taken from the poem "Sympathy" by the great black poet, Paul Laurence Dunbar. The title means that African Americans must have a voice in order to earn freedom.

Maya Angelou was herself a caged bird, but she broke those bars and soared high in the sky beyond the reach of any human cage. "Cages" are things that restrict people and Angelou's cage manifests the black, poor and triply marginalized female. She has been looked down upon for being black, has lived in those segregated black tenements, and as such witnessed the poverty and displacement of the black community in America. As Hilton Als states that I Know Why the Caged Bird Sings marked one of the first times that a black life writer could, as he puts it, "write about blackness from the inside, without apology or defense" ("Maya Angelou Poems: Reception and Legacy," web. 21 Jan. 2017).

Angelou was born in St. Louis, Missouri on 4 April 1928, and was named Marguerite Johnson. She was a daughter of Vivian Baxter Johnson and Bailey Johnson and had a brother, Bailey. Marguerite Johnson relates her experience of displacement as she moves from one place to another with her brother Bailey to be raised by different family members. After their parents' divorce, three year Marguerite, and four year brother Bailey, are shipped all alone from California to Stamps, Arkansas to their grandmother, Mrs. Annie Henderson, with tags on their wrists - "To Whom It May Concern" (I Know Why the Caged Bird Sings 5). She does not remember much about the trip, but after they reach the segregated south, Negro passengers give them food to eat feeling sorry for the poor little motherless darlings, left alone by their parents to cover such a long journey unlike any white child. As young children, Marguerite and Bailey struggle with pain of being rejected and abandoned by their parents. 
Marguerite is disheartened to be sent alone by their parents at such a tender age. However years later she discovers that the United States had been crossed thousands of times by the frightened black children traveling alone to their newly affluent parents in northern cities or back to grandmothers in Southern towns when the urban North reneged on its economic promises. Thus black children have had to suffer for being born to black parents, who neither could afford them a better life like white children, nor could accompany them on such journeys.

The segregated southern town of Stamps reacts to the newcomers as they had reacted to all new things. They regard kids with caution and when they are considered harmless, the people of the town "closed in around us, as a real mother embraces a stranger's child" (6). In Stamps they live with their grandmother who runs Wm. Johnson General Merchandise Store, "the only Negro store in Stamps" (12), with crippled Uncle Willie, the son of Mrs. Annie Henderson. The grandmother, usually called 'Momma' by the kids, is a successful business woman in Stamps. Along with a mobile lunch counter, she also helps the workers by giving them money on interest. In the heart of the black section of town, the Store provides food and all sorts of articles for the cotton pickers who work in the surrounding fields.

Most of the population of Stamps comprises of poor black peasants who work as cotton pickers on "the remains of Slavery's plantations" (7). The white ruthless masters are tyrannical and oppressive with no humane feelings for the poor black peasants who are made to work as slaves picking cotton in the fields for meager wages. In the morning Store is filled with "laughing, joking, boasting and bragging," workers, the tired field workers would "fold down, dirt-disappointed, to the ground" (8) at the end of the day. They toil hard the whole day with no reward and Angelou describes their predicament, "No matter how much they had picked, it wasn't enough. Their wages wouldn't even get them out of debt to my grandmother, not to mention the staggering bill that waited on them at the white commissary 
downtown" (8). Against the discrimination towards the blacks of Stamps, they had to unite together in order to overcome the misfortune. A feeling of fellowship and brotherhood is in the black community for they suffer at the hands of the whites in one way or the other.

Physical hardships like, "the fingers cut by the mean little cotton balls" (8) are minutely observed by her at Momma's store. Black people are in a cave chained to cotton, held by poverty and ignorance. They are treated like slaves by the white masters, even after the abolition of slavery. They work hard every day to earn enough for the whole year knowing pretty well that they would end up the season as they had started. Angelou describes the hopelessness of the cotton pickers who are victims of the system, "In cotton-picking time the late afternoons revealed the harshness of Black Southern life, which in the early morning had been softened by nature's blessing of grogginess, forgetfulness and the soft lamplight" (9). The rigid caste system of the South during the Great Depression is realistically portrayed by Angelou through the tragic plight of the poor black peasants. The white cotton balls which exact incessant labour from the black peasants are symbolic of the tyranny and oppression of the white man, whose humane feelings are never aroused by the innumerable sufferings of the poor black peasants.

The revival meetings ignite anger in Marguerite, she questions the lifestyles of peasants and their quiet acceptance of hard work. When the cotton-pickers return from fields, “Their minds sagged. In the Store the men's faces were the most painful to watch, but I seemed to have no choice. When they tried to smile to carry off their tiredness as if it was nothing, the body did nothing to help the mind's attempt at disguise," (120) they are back to the Store from where they had started in the morning. "The women's feet had swollen to fill the discarded men's shoes they wore" (121). Marguerite is disheartened to see her people working like oxen who struggle to survive pitiful existence. She considers it shameful that they try "to pretend that things were not as bad as they were," and she yearns to make them 
stand up and "assume the posture of a man" (121), than being treated like an animal all through their lives.

In spite of facing innumerable hardships they lean on God's mercy having full faith in the merciful master. According to the minister of the revival meeting God loves the poor and hates the rich and adds that the black man can assure his place in the land of milk and honey by suffering on this earth and being charitable. The collection comes last in the service and the revival members give from their small means in the name of charity. "They basked in the righteousness of the poor and the exclusiveness of the downtrodden. Let the whitefolks have their money and power and segregation and sarcasm and big houses and schools and lawns like carpets, and books, and mostly - mostly - let them have their whiteness. It was better to be meek and lowly, spat upon and abused for this little time than to spend eternity frying in the fires of hell" (131). Thus the blacks are trapped in a life of drudgery and exploitation; though the church preaches big words like charity and forgiveness to the blacks, the whites are kept out of the responsibility of being charitable to their fellow humans. The blacks are exploited even in the name of religion still they exult in the righteousness and promise of heavenly bliss after death. They are victims of discrimination of the South and ask God how long they have to suffer on this earth.

"The position of the girl child in India is still more deplorable, primarily because the discrimination against girls is rooted in our social and cultural prejudices which value son as an asset but look upon a girl as a liability and a drain on the resources of the family... As such, the birth of a female child is often viewed with disappointment and at best, indifference" (Luthra 63). The novel Nectar in a Sieve by Kamala Markandaya exposes the traditional attitude of Indians towards a female child right from her birth. "Rukmani's disappointment at the birth of a girl child is typical in India, especially for Indian farmers who need manpower for reaping and harvesting. Her reaction at the sight of the first-born is, 
"what woman wants a girl for her first-born?" (19). She sheds tears of weakness and disappointment. She supports her husband's view that "a male child is an asset and a girl child is a liability to the family" (Varghese 16). Preference for son over daughter is common throughout the world, be it India or America. In I Know Why the Caged Bird Sings Angelou's brother, Bailey is loved more than her and he enjoys free life as compared to her because he happens to be a boy.

In Marguerite's world Bailey is the "greatest person" (21) and she feels it her good fortune that he is her brother only and she need not share him with anyone else. She compares herself to her brother and tells how handsome he is in contrast to her: "Where I was big, elbowy and grating, he was small, graceful and smooth. When I was described by our playmates as being shit color, he was lauded for his velvet-black skin. His hair fell down in black curls, and my head was covered with black steel wool. And yet he loved me" (22). It is very painful for her that she was the only ugly child in a handsome family. "Pecola Breedlove, an unloved, 'ugly' 11-year-old Black girl in Toni Morrison's novel The Bluest Eye (1970), internalizes the negative images of African-American women and believes that the absence of blue eyes is central to her 'ugliness.' Pecola cannot value her Blackness - she longs to be White so that she can escape the pain of being Black, female, poor, and a child" (Collins 102).

Angelou relates the dissatisfaction with her looks with lack of love and abandonment, and believes that her quest for love can only be actualized through beauty. She associates being beautiful with the set standards of the "blond-blue-eyed-angel-like" girl and connects this standard to social acceptance. Family members, friends and neighbours remind her about her ugliness time and again. Bell hooks in Outlaw Culture: Resisting Representations describes the colour-caste system mentioned above as a practice that values lighter shades of blackness as better and more beautiful, "the lighter one's skin, the greater one's social value" 
(203). Bailey is her protector and comes to her defense when adults say unkind things pertaining to her physical appearance. He is also an all-time partner and companion to her. For Marguerite her "pretty Black brother was my Kingdom Come" (23) and "he was the pride of the Henderson/Johnson family," (22) and she loves her brother immensely.

I Know Why the Caged Bird Sings begins with a prologue wherein Marguerite painfully remembers a terrible day when she had to recite a poem at the church on the occasion of Easter in a new dress which she had imagined to be very beautiful, which actually is "a plain ugly cut-down from a white woman's once-was-purple throwaway," (2) she thinks "I was going to look like one of the sweet girls who were everybody's dream" (2). Marguerite is a black, poor female with "skinny legs," "small and squinty" eyes and "kinky mass" of hair (2). She fails to fulfill even the black standards of beauty. "Her sense of impotence and worthlessness is underscored in the opening pages when she dreams of waking up transformed into a beautiful white girl with blond hair and blue eyes" (MegnaWallace 4). She believes that she is actually white but a wicked jealous fairy had turned her "into a too-big Negro girl, with nappy black hair, broad feet and a space between her teeth that would hold a number-two pencil" (3). She feels herself to be an ugly black child who would never measure up to the standards of pretty white girls. Dealing with prevailing standards of beauty - particularly skin color, facial features, and hair texture - is one specific example of how controlling images derogate African American women. A children's rhyme often sung in Black communities proclaims:

Now, if you're white you're all right, If you're brown, stick around,

\section{But if you're black, Git back! Git back! Git back!}

Prevailing standards of beauty claim that no matter how intelligent, educated, or "beautiful" a Black woman may be, those Black whose features and skin color are most 
African must "git back." "Within the binary thinking that underpins intersecting oppressions, blue-eyed, blonde, thin White women could not be considered beautiful without the Other Black women with African features of dark skin, broad noses, full lips, and kinky hair" (Collins 97-98).

The cultural idea of 'Black Is Beautiful' - the reclamation of African American beauty - rises up from these pages as "Angelou writes about growing up in a world that equates beauty with whiteness" (Sickels PDF). The prologue conveys Marguerite's displacement in the already marginalized black community. The preface states, "If growing up is painful for the Southern Black girl, being aware of her displacement is the rust on the razor that threatens the throat" (4). She is fully aware of the hardships a young southern black girl will have to face in a racially discriminated and segregated society. The racist society convinces her that she can be nothing more than a poor black girl in a white man's world. In the Southern Humanities Review titled "The Song of a Caged Bird: Maya Angelou's Quest after Self Acceptance," Sidonie Smith says that this "primal childhood scene brings into focus the nature of the imprisoning environment from which the self will seek escape. The black girl child is trapped within the cage of her own diminished self-image around which interlock the bars of natural and social forces" (368).

One Christmas Marguerite and Bailey receive gifts from their parents who lived separately in California, they feel sad on receiving the gifts and go out and cry. Marguerite had thought her parents to be dead till she receives gifts from them on Christmas. Her father sends his photograph and her mother sends her a tea set and a doll "with blue eyes and rosy cheeks and yellow hair painted on her head" (52). The gifts brought up so many questions to their mind as to what wrong had they done that their parents sent them alone from California to Stamps at the age of three and four with tags put on their arms. The parents fail to understand the feelings of their little kids and gift a blue eyed doll which ironically pictures 
the white standard of beauty. Both of them tear the stuffing out of the doll as revolt against the unattainable standards of beauty and save the tea set in case their parents return. In The Bluest Eye (1970), Toni Morrison presents the character of Claudia, a 10-year-old Black girl who, "to the chagrin of grown-ups, destroys White dolls by tearing off their heads and who refuses to share her classmates' admiration of light-skinned, long-haired Maureen Peal. Claudia's growing awareness of the 'Thing that made her [Maureen Peal] beautiful and us ugly' and her rejection of that Thing - racist images of Black women - represents yet another reaction to negative images of Black womanhood" (Collins 104).

One day her father, Bailey Henderson Sr., comes to Stamps who is very handsome and Marguerite thinks that Bailey is his son for he was as handsome as their father and that she "was an orphan that they picked up to provide Bailey with company" (55). For three weeks people who had gone to school with her father or heard about him came to meet him. To Marguerite her father "sounded more like a white man than a Negro. Maybe he was the only brown-skinned white man in the world" (58). She gets very upset to know that their father has come to take them with him to St. Louis to their mother as she does not want to leave Momma. She does not even care about anything during the journey, all she knows is that, "we were being driven to hell and our father was the delivering devil" (59). When they reach St. Louis and meet their mother, Bailey falls in love with her at first sight. Marguerite realizes that because their mother is too beautiful to have children so she had sent them away as "unwanted children" (60). Both children are amazed at the beauty of their mother, she is modern, open, strong minded and supports her children "efficiently with humor and imagination" (207). She is a very positive person and refuses to be subservient to men or white people.

Marguerite struggles to accept herself and her body even though she feels inferior to others. Uncle Tommy, her mother's brother, used to tell her often, "Ritie, don't worry 'cause 
you ain't pretty. Plenty pretty women I seen digging ditches or worse. You smart" (67). Though her brain is appreciated but her belief in her ugliness is affirmed further. Angelou writes in a letter to her friend Rosa Guy, "My belief [as a child] that I was ugly was absolute, and nobody tried to disabuse me - not even Momma. Momma's love enfolded me like an umbrella but at no time did she try to dissuade me of my belief that I was an ugly child" (qtd. in Braxton, Maya Angelou's I Know Why the Caged Bird Sings: A Casebook 24).

In St. Louis, Marguerite notices how the marginalized Negro community is plunged into the world of crime, paying no heed to law and order. She becomes a victim of male oppression and exploitation when Mr. Freeman, her mother's boyfriend, molests and rapes her at the tender age of eight. She confuses his embrace with paternal love and affection when he first molests her: "From the way he was holding me I knew he'd never let me go or let anything bad ever happen to me. This was probably my real father and we had found each other at last" (73). Mr. Freeman threatens to kill Bailey if she tells anything to anybody. Subsequently Mr. Freeman rapes her, which is physically and mentally painful, she considers herself guilty of some forbidden crime and keeps the incident a secret out of fear and guilt, though she is sick with terrible pain. She thinks, "What he did to me, and what I allowed, must have been very bad if already God let me hurt so much" (81). Mr. Freeman chooses the weakest target, a black female child, to exert his cruel male power, symbolizing the tyranny of a sexist society.

Later the family hospitalizes her, she feels like spending the rest of her life in the hospital as she relishes the attention, love, care and protection given to her by the Baxter family. "Mother brought flowers and candy. Grandmother came with fruit and my uncles clumped around and around my bed, snorting like wild horses. When they were able to sneak Bailey in, he read to me for hours," (83) literature has therapeutic effect on her mind and body and she looks forward to such reading sessions. In the court, Freeman's lawyer 
symbolizes male oppression as he verbally brings in the whole incident of rape. He belittles her in the name of justice and asks her to her dismay, "Do you know if you were raped?" (84). She denies any prior physical contact with Mr. Freeman because she fears that her uncle will kill her, her grandmother will get angry and stop talking to her, her mother will be disappointed and Bailey will know that she had kept a secret from him. "And all those people in the court would stone me as they had stoned the harlot in the Bible" (85). She prefers retreating into silence than answering the lawyer's intimidating questions after experiencing extreme physical and mental turmoil. The rape of a child is the cruelest action as Angelou shares why she writes about her rape, "You write so that perhaps people who hadn't raped anybody yet might be discouraged, people who had might be informed, people who have not been raped might understand something, and people who have been raped might forgive themselves" (Braxton, Maya Angelou's I Know Why the Caged Bird Sings: A Casebook 12).

The court of law punishes Mr. Freeman for one year and one day but someone gets him released that very afternoon. Marguerite comes to know that he had been found kicked to death, probably by her uncle. She feels that Mr. Freeman was dead because she told a lie in the court. She decides to stop talking or someone else might die. "I could feel the evilness flowing through my body and waiting, pent up, to rush off my tongue if I tried to open my mouth. I clamped my teeth shut, I'd hold it in" (86-87). Except her brother, she communicates with no one and remains mute for a number of years. Her family accepts her behavior as a "post-rape, post-hospital affliction," (87) but even after doctor tells that she is healed, she refuses to be the child she once was. Even after necessary punishments and thrashings she does not retain her normal self and is "called impudent," (88) she copes up with the rape by refusing to talk. "The context of silence is varied and multi-dimensional. Most obvious are the ways racism, sexism, and class exploitation act to suppress and silence" (hooks, Talking Back 8). Her innocence is stolen from her and she is not a carefree child 
again. After some time the loving and caring Baxter family gets fed up with her silence and grim presence, and sends Marguerite and Bailey back to Stamps in the care of their loving grandmother, Mrs. Henderson. The people of Stamps accept Marguerite's muteness, she feels relaxed in the Southern community and thinks that the barrenness of the small Southern town is just what she wants.

The oppression of women stems largely from men's desire for power and control. The same need which, throughout history, has driven men to try to conquer and subjugate other groups or nations, and to oppress other classes or groups in their own society, drives them to dominate and oppress women. "Since men feel the need to gain as much power and control as they can, they steal away power and control from women. They deny women the right to make decisions so that they can make them for them, leave women unable to direct their own lives so that they can direct their lives for them" (Taylor, web. 30 Aug. 2012). The society is constructed on the historical notion that men are stronger, dominant, capable, superior, stronger and knowledgeable than women.

In I Know Why the Caged Bird Sings Maya Angelou recounts the events of her life in chronological order amidst the racist and sexist American society. Her life is full of ups and downs but in spite of her trials and tribulations she finds a way to accomplish her goals. "Angelou shows how to be black and female is to be oppressed twice, and that for black women to survive, they must be strong" (Sickles PDF). She portrays most of her difficult life events from the age of three to sixteen in her life writing showing her hard upbringing, poverty, racism and sexual abuse. She undergoes painful experiences in life but eventually succeeds in overcoming them. She suffers tremendous hardships in her life and her life writing visualizes all the hardships Angelou faced and for women across the globe Angelou's life is a source of inspiration and immense strength. She says, "All my work, my life, everything I do is about survival, not just bare, awful, plodding survival, but survival with 
grace and faith. While one may encounter many defeats, one must not be defeated" (qtd. by Haas 300). bell hooks avers in her book Talking Back, "It has been a political struggle for me to hold to the belief that there is much which we - black people - must speak about, much that is private that must be openly shared, if we are to heal our wounds (hurts caused by domination and exploitation and oppression), if we are to recover and realize ourselves" (3). The longing to tell one's story and the process of telling is symbolically a gesture of longing to recover the past in such a way that one experiences both a sense of reunion and a sense of release. Writing their lives is a way to evoke the particular experience of growing up southern and black in segregated communities and a way to recapture the richness of southern black culture. Bringing one's past and memories together in a complete narrative allows one to view them from a different perspective, "not as singular isolated events but as part of a continuum" (hooks, Talking Back 159). Life writing enables them to look at their past from a different perspective and to use this knowledge as a means of self-growth to usher change in an emphatic way. 


\section{Works Cited}

Primary Sources:

Angelou, Maya. I Know Why the Caged Bird Sings. New York: Random House, 1969. Print.

Secondary Sources:

Bell-Scott, Patricia. Life Notes: Personal Writings by Contemporary Black Women. New York: Norton, 1994. Print.

Braxton, Joanne M., ed. Maya Angelou's I Know Why the Caged Bird Sings: A Casebook. New York: OUP, 1999. Print.

Collins, Patricia Hills. Black Feminist Thought: Knowledge, Consciousness, and the Politics of Empowerment. New York: Routledge, 2000. Print.

Haas, Michaela. Bouncing Forward: Transforming Bad Breaks Into Breakthroughs. New York: Enliven, 2015. Print.

hooks, bell. Outlaw Culture: Resisting Representations. New York: Routledge, 1994. Print.

---. Talking Back: Thinking Feminist, Thinking Black. Boston: South End Press, 1989. Print.

Luthra, H.L. A Textbook of General Studies. 12th ed. New Delhi: Pitambar Publishing Company, 2006. Print.

Markandaya, Kamala. Nectar in a Sieve. New Delhi: Penguin Books, 2009. Print.

Megna-Wallace, Joanne. Understanding I Know Why the Caged Bird Sings: A Student Casebook to Issues, Sources and Historical Documents. U.S.A.: Greenwood Press, 1998. Print.

Varghese, Lata Marina. A Land of One's Own: Women and Land Rights in Literature and Society. U.K.: Cambridge Scholars Publishing, 2015. Print.

Wade-Gayles, Gloria. No Crystal Stair: Visions of Race and Sex in Black Women's Fiction. New York: The Pilgrim Press, 1971. Print. 
Journals and Reviews:

Smith, Sidonie. "The Song of a Caged Bird: Maya Angelou's Quest after Self Acceptance." Southern Humanities Review 1973: 365 - 75. Print.

Internet Sources:

"Go There To Know There: Phillis Wheatley: African American Foremother of Poetry." Web. 13 Sept. 2016. <gotheretoknowthere.blogspot.com/2010/09/phillis-wheatleyand-david-walker.html>.

"Maya Angelou Poems: Reception and Legacy." Web. 21 Jan. 2017. <www.gradesaver.com/maya-angelou-poems/wikipedia/reception-and-legacy>.

Taylor, Steve. "Why Men Oppress Women: The psychology of male domination.” 30 Aug. 2012. Web. 10 Feb. 2017. <https://www.psychologytoday.com/blog/out-thedarkness/.../why-men-oppress-women>.

PDF File:

Scott, Robin Patricia. "Being Black and Female: An Analysis of Literature by Zora Neale Hurston and Jessie Redmon Fauset." 1986. PDF File. Web. 2 Jan. 2017. <https://dspace.mit.edu/bitstream/handle/1721.1/33806/17940803-MIT.pdf> .

Sickels, Amy. "I Know Why the Caged Bird Sings: African American Literary Tradition and the Civil Rights Era.” 2010. PDF File. Web. 27 Jan. 2017. <salempress.com/store/pdfs/caged_critical_insights.pdf>. 